\title{
Chapter 11 \\ From Extreme Poverty to the Social \\ Question. Well-being and Sustainability Around 1910
}

\author{
Harry Lintsen
}

\section{Contents}

11.1 'The Material and Spiritual Side of the Social Question'.....

11.2 Building a New Corporatism: Citizens, Government, Entrepreneurs and

Researchers.

11.2.1 A New, Dynamic, Civil Society...................................................................... 220

11.2.2 The Birth of the Welfare State...................................................................... 222

11.2.3 The Emergence of a Modern Economy....................................................... 224

11.2.4 The Foundations of a Modern Knowledge Infrastructure .............................. 226

11.3 The Monitor of 1910: Well-being and Sustainability from Three Perspectives........... 227

11.3.1 Perspective 1850: An Enticing Paradise.............................................................. 230

11.3.2 Perspective 1910: The New Agenda of the Turn of the Century..................... 231

11.3.3 Present-Day Perspective: Related and Deviant Values..................................... 231 Literature

\begin{abstract}
The dynamics of the resource-production-consumption chains as analysed in the three previous chapters were interrelated with the dynamics of societal institutions. The strategies of professional groups and political parties eventuated in a corporatist state structure, with a societal midfield solidly anchored in a political system and in a state bureaucracy at local, provincial and national levels. New notions about extreme poverty and well-being acquired a legal framework around 1900, within which governments, entrepreneurs, citizens and workers could continue to work on the solution of different issues. The legal framework was also the origin of the welfare state as it would develop in the course of the twentieth century. The modernising economy was also characterized by the emergence of new professional groups and a modern knowledge infrastructure.

This is the context in which we must place the well-being monitor for 1910 . Well-being and sustainability around 1910 are viewed from three perspectives. Judged by the societal agenda of 1850 much progress had been made, especially in regard to extreme poverty. But the societal agenda of 1910 shows that opinions about poverty have shifted and that in this period the qualities of the food supply, of public health facilities, of public housing and of work are the core issues. The
\end{abstract}


present-day perspective on well-being differs little from that of 1910. But in regard to the issue of sustainability there are big differences.

Keywords Corporatism - Social question · Knowledge infrastructure · Monitor · Public health $\cdot$ Public housing $\cdot$ Labour

\title{
11.1 'The Material and Spiritual Side of the Social Question'
}

\begin{abstract}
The general condition of the people in many respects compels us to be thankful. However, we should not ignore the fact that, both on the spiritual and material levels, a change in circumstances has come about that requires the government, more than hitherto, to give leadership and provide support ... Not less does the material side of the social question continue to draw My attention. ${ }^{1}$
\end{abstract}

The Queen's speech to parliament, delivered by Queen Wilhelmina in 1901 from a text provided by the confessional government of prime minister Abraham Kuyper, outlined the new role that the national government had taken upon itself in the development of well-being. "More than hitherto' the national government decidedly saw a role for itself.

The Netherlands had just experienced two decades of prosperity. The growth indicators of the GDP were among the highest in the century. The magnitude of extreme poverty had shrunk to a historic low point. It was surely one of the reasons why Kuyper was satisfied with the 'general condition of the people.' The 'change' that was mentioned in the Queen's speech had to do with the Christian nature of the cabinet. Protestant Anti-Revolutionaries and Catholics had won the elections. Kuyper's cabinet took office after a period of three liberal cabinets.

What details did the Queen's speech provide for the 'spiritual and material' side of the social question? The 'material side' was a mixture of labour and povertyrelated measures. The cabinet wanted to stop the emiseration of the vulnerable members of society by means of mandatory insurance against the consequences of illness, invalidity and old-age. They wanted to combat fraud with food supplies in order to protect the population against malnutrition. Mandatory insurance against industrial accidents served to protect vulnerable workers. New apprenticeship regulations sought to improve popular education. On the 'spiritual side' Kuyper's government wanted to uplift 'the moral character of public life' in particular to rein in 'addictions to games and drink.' And then of course there was the issue of special education that had already occupied politicians and the churches for years. The confessional parties wanted to have religiously-based schools subsidised by the government, in addition to the regular non-denominational public schools.

\footnotetext{
${ }^{1}$ Queen's address to parliament by Queen Wilhelmina, 17 September 1901. At www.troonredes.nl (consulted 26-9-2014).
} 
Quite striking is the attention paid to the "lesser welfare of the native population on Java.' The cabinet would take action on this issue and, among other things, closely monitor obedience to the regulations designed to protect native coolies.

But parliamentary opposition prevented the cabinet from making good on its ambitious social programme. To make matters worse, the big Railway Strike of 1903 seriously dented its image. Kuyper collided with striking railway workers and stevedores, whom he accused of 'criminal agitation.' Three laws were adopted 'strangulation laws' according to the socialists - that prohibited civil servants and workers in key sectors (like the railways) from striking. This broke the strike. It was only in the area of colonial politics that the cabinet was able to cash in on its promises, particularly the introduction of the 'ethical policy' that aimed to promote the political and economic independence of the colonial population.

Poverty dominated the issue of well-being throughout the nineteenth century. A low quality of life was passed on through successive generations of the poor. Contemporaries acknowledged the seriousness of the issue, even as it took on a different guise in the course of the century. Around 1850 poverty was associated with extreme poverty. An important segment of the population had to make do without the minimal basic necessities like food, drink, clothing, warmth and housing. The struggle against poverty was initially aimed at providing for these minimal needs.

But in the course of time the issue became broader. Foreign reports about slums in the growing cities, about the miserable conditions in factories and about the exploitation of the proletariat on the one hand horrified the Dutch bourgeoisie and on the other hand incited fear of uprisings and revolution. When the first 'modern' strikes took place in 1869 - albeit on a modest scale - they stimulated a wide range of responses. One of them was the founding of the 'Committee for deliberating the Social Question' in 1870. The term 'Social Question' would become the dominant referent for a wide range of problems around poverty, extreme poverty, public health, public housing, popular culture and labour issues. ${ }^{2}$

At the time this also included qualitative aspects: the emphasis was no longer solely on the bare the survival of the poor, but rather on a life that was as healthy as possible; not only on sufficient food, but also on healthy food; not only on a roof over one's head, but just as much on a dwelling with hygienic facilities; not just on work, but also on skilled work under good working conditions. It was, finally, felt that the poor should not be obsequious, but above all 'civilized.'

After that things moved quickly. The Netherlands were faced with an increasing number of slums in rapidly growing cities. The modernisation of the economy made labour relations more distant and formal. The factory system began to penetrate into regions like Twente and North Brabant. The increase in the number of voters was also an important development. The constitutional reform of 1887 endowed many more citizens with voting rights. In $188012.3 \%$ of the male population could vote.

\footnotetext{
${ }^{2}$ See among others: J.L van Zanden and A. van Riel, Nederland 1780-1914: Staat, instituties en economische ontwikkeling (Amsterdam 2000), 314-317; E. Nijhof and A. van den Berg, Het menselijk kapitaal: Sociaal ondernemersbeleid in Nederland (Amsterdam 2012), 47-52.
} 
In 1890 that had increased to $26.8 \% .^{3}$ New social groups joined in the political process and hence acquired potential access to state power. Numerous organisations profiled themselves as protagonists of specific interests. Many claimed to be able to offer solutions to the social question. This issue would occupy a prominent place on the societal agenda around 1900.

In preceding chapters these shifts have been briefly noted. In this chapter we will summarize them and elaborate further. Who were the bearers of the new perspectives on poverty and quality of life? How and under what circumstances did they succeed in turning this into a political item? Why did this debate lead to an active role for a government that had formerly been passive in social matters?

The scope of extreme poverty declined in the nineteenth century. This development was embedded in trade-off processes. To what extent was the increase in quality of life paid for by the natural environment and the exploitation of natural capital? To what extent was depletion of resources elsewhere part of the picture? How sustainable was the new situation? The chapter closes with an evaluation of the situation at the outset of the twentieth century based on the monitor for well-being.

\subsection{Building a New Corporatism: Citizens, Government, Entrepreneurs and Researchers}

\subsubsection{A New, Dynamic, Civil Society}

After a period of near dormancy under King William I, the civil society came into its own in the second half of the nineteenth century. Farmers' organisations had organised themselves nationally. Workers first organised locally, then nationally. Associations of manufacturers followed in their wake. The rise of the labour movement led to the founding of the Netherlands Workers' Union in 1869 as the Dutch branch of the First International. The first modern political party was the AntiRevolutionary party founded in 1879 . The socialists followed suit with the SocialDemocratic Federation in 1881, the liberals with the Liberal Union in 1886 and the Catholics with the Roman Catholic State Party in 1896. Then there were the professional organisations of physicians, engineers and economists and long-existing or newly founded associations with idealistic aims like the Society for the General Good of 1784 and the Peoples Federation against Alcohol Abuse of $1875 .{ }^{4}$

\footnotetext{
${ }^{3}$ Van Zanden and van Riel, Nederland 1780-1914, 314-315. Van Zanden and van Riel see the striving for the political and socio-cultural integration of new voters as one of the most important processes behind the rise of the social question, the struggle around special (religious) education, and the civilizing offensive after 1870. For figures, see table 7.1, 315.

${ }^{4}$ The People's Union against Alcohol Abuse (Volksbond tegen Drankmisbruik) was founded in 1875 under the name of Multapatior's Union against Intoxicating Spirits. In 1882 the name was changed to People's Union, Association against Alcohol Abuse, later referred to more briefly as People's Union against Alcohol Abuse.
} 
Civil society certainly flourished, but did it also develop into a force able to influence the government in regard to the social question? Organisations could pursue their programs in three main ways: via societal action, via governmental organisations or via a political party. For workers, strikes were the weapon of choice. Up to the end of the 1880s the number of strikes was limited, with a peak of 33 strikes in 1872. After that the number of strikes would increase rapidly up to the First World War, with a peak of 400 strikes in 1913. Most strikes were spontaneous and barely affected government policy in any direct sense. The railway strike of 1903 was a watershed. After that, a large part of the workers' movement opted for a mode of unionization based on solid and nationally organised unions capable of being a force in Dutch politics. ${ }^{5}$

Professionals opted for another strategy. The example of the hygienists - a new generation of young and progressive physicians - shows how successful they could be. ${ }^{6}$ The hygienists formed a solid national network, that was anchored in local medical associations and the national Society for the Promotion of Medicine (1849). They used this network to collect, exchange and tabulate statistics on diseases. They also created national standards for research protocols and the definition of diseases. This made the hygienists the most important suppliers of medical knowledge. Around 1870 their method of operation had been adopted by the government that in turn had assured itself of the cooperation of municipalities, citizens and physicians.

The hygienists also worked together with other groups on an hygienic programme that over the years came to include more than sanitary facilities. The quality of foodstuffs, public housing, working conditions and the establishment of new factories and workshops all came under their purview. An important role in this programme was played by the so-called health commissions, that had been set up in the 1850s and 1860s in a large number of municipalities and whose membership consisted of physicians, lawyers, scientists and engineers. A national breakthrough occurred in 1865 when a law was passed creating a State Medical Inspectorate. Almost all the hygienists became paid or unpaid staff of this State Inspectorate. In addition, every hygienist was member of a health commission or an association for promoting public health, often one they set up themselves. Sometimes they were members of city councils or became aldermen their cities. The medical community, and in particular the hygienists, thus acquired local influence on municipal health policy and national influence on emergent public health policy.

The third strategy - that of the political party - was initially developed by Abraham Kuyper. ${ }^{7}$ On the one hand Kuyper worked on a number of civil organisa-

\footnotetext{
${ }^{5}$ S. van der Velden, Stakingen in Nederland: Arbeidersstrijd 1830-1995 (second revised edition, Amsterdam 2009). For figures see the website of the International Institute for Social History, table with the number of strikes and shutouts per year, https://socialhistory.org/sites/default/files/docs/ overzicht-aantallen-stakingen.pdf

${ }^{6}$ See for the below analysis: E. Houwaart, 'Medische statistiek', in: H.W. Lintsen et al. (eds.), Geschiedenis van de techniek in Nederland: De wording van een moderne samenleving (Zutphen 1993), volume II, 19-45.

${ }^{7}$ See for the role of Abraham Kuyper in Dutch politics: P. de Rooy, Ons stipje op de waereldkaart: De politieke cultuur van modern Nederland (Amsterdam 2014), 126-133.
} 
tions to organize his protestant constituency and on the other on a political party that would maintain control over the civil initiatives and that would introduce protestant issues into parliament. Thus in 1869 he mobilised the existing Association for Christian National Schooling to start taking political action, in 1872 he was cofounder and founding chief editor of the journal The Standard, in 1878 he was instrumental in establishing the Free University in Amsterdam, and in 1886 he was the leader of the so-called Doleantie, a Calvinist current within the Dutch Reformed Church (Nederlandse Hervormde Kerk) that led to a schism and to the founding of the Reformed Churches in the Netherlands (Gereformeerde Kerken in Nederland). Finally he founded the Anti-Revolutionary Party on the basis of 'Our Program.'

It signified a revolution in political culture. Up to then, voters chose their representatives on the basis of their personal qualities. Ideally, parliamentarians were seated in parliament as independent persons and debated issues on the basis of their expertise and their interpretation of the general interest. A political party that defined the relevant political issues and stipulated who voters should choose as their representatives in parliament - as Kuyper was proposing - was anathema.

Other societal movements came to adopt Kuypers' strategy. This led at the outset of the twentieth century to a 'pillarised' social structure. Especially the confessionals and the socialists attempted to bring all the aspects of the lives of their constituencies - family, upbringing, education, habitation, work and leisure - within the sphere of influence of their own pillar. This consisted of a network of educational organisations, health care organisations, cooperative housing associations, sport associations, newspaper publishers, labour unions, farmers' organisations, employers' organisations and - in the case of a confessional pillar -churchly institutions.

Professional and party-political strategies led to the building of a new corporatism. ${ }^{8}$ In the course of the nineteenth century the remnants of an old kind of corporatism consisting of guilds, marks and other kinds of corporatist organisation in autonomously functioning cities, had been dismantled. In its place a corporatist state structure emerged that was characterised by a societal midfield that had lodged itself firmly in a political system and a governmental bureaucracy at local, provincial and national levels.

\subsubsection{The Birth of the Welfare State}

Political debate in the second half of the nineteenth century consisted to an important degree of issue that would later become the 'social question' and in particular addressed the role that the government should play. Thorbecke had already seen to it that the constitution included poor relief as a governmental responsibility. He stated that 'a civilized nation ... is duty bound to ensure as far as possible that its

\footnotetext{
${ }^{8}$ The thesis was proposed first by J. van Zanden and A. van Riel, see the section 'Collectieve actie en de opbouw van een nieuw corporatisme' in: Van Zanden and van Riel, Nederland 1780-1914, 322-329. Our analysis diverges somewhat, but the conclusion is the same.
} 
members do not perish from want. Charity on the basis of church membership cannot do this...' ${ }^{9}$ The Poor Law he submitted to parliament in 1851 was written in this spirit.

Opposition was fierce. According to the confessionals, the state had no business in this domain and the liberals regarded poor taxes as a thorn in their side. Hence the new poor law left everything as it was. A new attempt in 1901 to make poor relief a governmental responsibility encountered stiff resistance from the AntiRevolutionaries. The draft law was 'a bold attempt at violating the freedom of the churches.' Ultimately, the Poor Law of 1912 would mark the tentative beginnings of more state influence - namely by municipalities - on poor relief. ${ }^{10}$

As we saw, the government had made a modest incursion into the domain of public health in the 1850s and 1860s. The mandatory establishment of health commissions by municipalities was rejected by parliament. It did, on the other hand, accept the founding of a State Medical Inspectorate. The national government made almost no effort to improve public hygiene. In this area, several municipalities with their health commissions took the lead, like Rotterdam, Amsterdam, The Hague and Utrecht. ${ }^{11}$

While a young generation of physicians (the hygienists) was active in the political domain of public health, a young generation of engineers was similarly active in the domain of labour. ${ }^{12}$ The way had been paved by the social liberals, who were convinced that not everything could be left to the market. They demanded a greater role for the government in social issues. Parliamentarian Van Houten's 1874 Child Labour law was their first success. ${ }^{13}$ The parliamentary enquiries of 1887 and 1890 forced a breakthrough in the debate and placed the issue of labour squarely on the political agenda. A new generation of engineers, educated in Delft, had appropriated this domain and enthusiastically supported the work of two of their fellow engineers in three liberal cabinets between 1890 and $1901 .^{14}$ The engineer P. van der Sleyden succeeded as minister in shepherding a Safety Law through parliament in 1895 and bringing the Public Nuisance Act of 1875 and the Labour Law of 1889 together in an elegant fashion. The Labour Inspectorate, dominated by engineers and charged

\footnotetext{
${ }^{9}$ M. van Leeuwen, 'Armenzorg, 1800-1912: Erfenis van de Republiek', in: J. van Gerwen and M. van Leeuwen (eds.), Studies over zekerheidsarrangementen: Risico's, risicobestrijding en verzekeringen in Nederland vanaf de Middeleeuwen (Amsterdam 1998), 284-286, quote on p. 284.

${ }^{10}$ M. van Leeuwen, 'Armenzorg, 1912-1965: Van centrum naar periferie', in: J. van Gerwen and M. van Leeuwen (eds.), Studies over zekerheidsarrangementen: Risico's, risicobestrijding en verzekeringen in Nederland vanaf de Middeleeuwen (Amsterdam 1998), 284-286. Citation from: Van Leeuwen, 'Armenzorg 1800-1912', 294.

${ }^{11} \mathrm{H}$. Buiter, Riool, rails en asfalt: 80 jaar straatrumoer in vier Nederlandse steden (Eindhoven 2005). See also: A. van der Woud, Koninkrijk vol sloppen. achterbuurten en vuil in de negentiende eeuw (Amsterdam 2010), 257-259.

${ }^{12}$ H.W. Lintsen, Ingenieurs in Nederland in de negentiende eeuw: Een streven naar erkenning en macht (Den Haag 1980), 198-325.

${ }^{13}$ It prohibited children up to age 12 to work in factories. Notably, the prohibition did not apply to cottage industry, household services and agricultural labour.

${ }^{14}$ Lintsen, Ingenieurs in Nederland in de negentiende eeuw, 330-342.
} 
with the implementation of the Labour Law, now also began to monitor adherence to the Safety Law. Furthermore, the inspectorate was empowered to nullify municipal permits granted under the Public Nuisance Act if the installation in question violated the Safety Law. After this victory, Cornelis Lely (the engineer with the plans for the closure of the Zuiderzee) managed, as minister, despite vociferous resistance, to get parliament to pass a draft Accident Law. The editor of the journal De Ingenieur wrote on this occasion:

Lely has demonstrated once again that in social matters he is in the vanguard, straight through storms and heavy seas, never quitting his post, and in the process defying not only big industrialists but even more the objections advanced against his bill in the First Chamber $\ldots{ }^{15}$

The objections addressed above all the practical application of the law. Who would organise the accident insurance and bear the risks? Should that be left to the state or to civil society, in particular the employers? A compromise seemed to be the only workable solution.. Employers could have recourse to a Government Insurance Bank, but also to an insurance company. They established their own cooperative insurance company, Centraal Beheer. Nonetheless, the Government Insurance Bank was given a supervisory and policy role.

A similar question troubled the Housing Law of 1901 that aimed at improving public housing. This was ambivalent about whether government, private enterprise or citizens should take the initiative. The law enabled the government to subsidise certified housing associations and contractors who were exclusively committed to the interests of public housing.

By 1900 the social question had acquired a legal framework within which 'pillars,' governments, entrepreneurs, citizens and workers could proceed in solving different issues. In retrospect the legal framework can also be seen as the origins of the 'caring state' as that would develop in the twentieth century. After this period, well-being and quality of life acquired an entirely new dynamic.

\subsubsection{The Emergence of a Modern Economy}

From the 1840s on the Dutch economy underwent a radical transformation. It began with the liberalisation of foreign trade that cleared the way for the globalisation and accelerated integration of international markets. It encountered opposition from Dutch manufacturers. Various Chambers of Commerce and Factories called for protection for domestic industry because, 'every nation...must attempt to shield its trade and agriculture from being taken unawares and being destroyed by jealous neighbours. ${ }^{16}$ The government and parliament paid little heed to these appeals.

\footnotetext{
15 'Uit Ons Parlement', De Ingenieur 15(1900), 663. Quotation in: Lintsen, Ingenieurs in Nederland in de negentiende eeuw, 342.

${ }^{16}$ J.C.G. Schulte 'De Kamer van Koophandel en Fabrieken, 1842-1862' in: De opkomst van Tilburg als industriestad: Anderhalve eeuw economische en sociale ontwikkeling, 88-96. Zie ook:
} 
They also succeeded in achieving an integration of domestic markets by means of legislation and the creation of new infrastructures. Modernisation of the economy subsequently proceeded along many fronts. Accelerated integration of the service sector came about with innovations on the money and capital markets. The production ceiling in agriculture was shattered thanks to specialisation and artificial fertiliser, while with the coming of artificial fertiliser the circular economy of the food chain changed into a linear one. Steam technology broke through the production ceiling in small firms and stimulated specialisation and the rise of large enterprises.

The relationships in the economy also changed because different groups tried to co-opt the modernisation process and exercise influence on the national government. Farmers' organisations had gone nationwide after 1850, founded cooperatives in the 1890 s and since then worked closely with the government. Workers' associations were long a local phenomenon (with Amsterdam often in the vanguard) and organized by trade (with type-setters and diamond cutters as pioneers). Fifteen trade unions joined forces in 1906 and founded the Netherlands Association of Trade Unions. In 1909 several unions formed the Christian Trade Association and in 1912 the catholic union movement united in the Roman Catholic Workingman's Association.

Employers organisations followed a similar course. They began locally and by sector, especially in response to emerging workers' opposition. This was followed by national cooperation. The Association of Netherlands Employers of 1899 was the first important national employers' organisation. It emerged from worries within the group of textile factory owners in Twente with regard to the Accident Law that was then in preparation. Pillarisation of the employers' organisations mimicked that of the workers' unions. In 1907 there were 307 local and 35 national associations. ${ }^{17}$ Factory owners did not react only in a defensive way to the workers' movement, socialism and the social question. Some, including Van Marken of the Delft yeast factory, the machine-builder Stork in Hengelo and the linen weaver Van Besouw in Goirle launched initiatives such as profit sharing, housing for workers and funds for ill, invalid and older workers. ${ }^{18}$

The modernising economy was also characterised by the rise of new professional groups. These included in particular mechanics, chemists, engineers, lawyers and physicians. They were the representatives of a modern knowledge infrastructure.

\footnotetext{
H.W. Lintsen and J. Korsten, De veerkracht van de Brabantse economie: De Kamers van Koophandel en de kracht van netwerken [1840-2015] (Hilversum 2007).

${ }^{17} \mathrm{~B}$. Bouwens and J. Dankers, Tussen concurrentie en concentratie: Belangenorganisaties, kartels, fusies en overnames (Amsterdam 2012), 55.

${ }^{18}$ Nijhoff and van den Berg, Het menselijk kapitaal, 47-48.
} 


\subsubsection{The Foundations of a Modern Knowledge Infrastructure ${ }^{19}$}

One of the most essential elements of the modern technological knowledge infrastructure was 'codified' knowledge. In craft-based manufacture, knowledge was mostly 'tacit,' that is to say embedded as non-reflexive routines in the heads and limbs of people. It was nearly impossible to explicate and could be acquired only through intensive practice. Knowledge was transferred from master to apprentice or by means of other modes of face-to-face contact. The development of knowledge occurred in practice, and communication took place via the spoken word and body language.

'Codified' knowledge was explicated knowledge, knowledge that was expressed in the written and printed word. Knowledge and communication were in principle no longer bound to one person and were hence de-contextualised in time and place. Books and articles could be consulted at any time. They could be preserved through time and consulted at different places. 'Codified' knowledge also expressed itself in more precise measuring and more systematic testing and experimentation. This knowledge was easier to share with others by means of printed books and journals. It could thus acquire a collective character, that is to say, become available to a professional community and the interested public.

The construction of a modern knowledge infrastructure in the second half of the nineteenth century took place to a great extent around 'codified' knowledge: new technological programs of study with their textbooks, new associations with their journals, new technical services with their technical literature and new laboratories with their scientific publications. This construction took place at all levels.

Technical education, for example, comprised the trade schools (the first dating from 1860), middle-level technical schools (like the Amsterdam School for Machinists, founded in 1878) and the Polytechnical School dating from 1864 (the successor to the Delft Academy for Engineers of 1842, that would in turn be transformed into the Technical High School, complete with the ius promovendi, in 1904), while the universities educated physicists and chemists. Many of the schools owed their existence to private initiative. The Polytechnical School and the universities were financed by the government.

Until 1890 only a modest number of students were enrolled in technical education. After 1890 their numbers increased rapidly. The trade schools, in particular, exhibited phenomenal rates of growth from about 1100 students in 1890 to more than 10,000 in $1915 .^{20}$ The Delft engineering school also profited from an increased interest in, among others, mechanical engineering, electrical engineering and chem-

\footnotetext{
${ }^{19}$ See for this section: M. Davids, H.W. Lintsen and A. van Rooij, Innovatie en kennisinfrastructuur: Vele wegen naar vernieuwing (Amsterdam 2013), 37-42; 52-64.

${ }^{20}$ P. Baggen and E. Homburg, 'Opkomst van een kennismaatschappij', in: J. Schot, H. Lintsen, A. Rip and A. Albert de la Bruhèze (eds.), Techniek in Nederland in de Twintigste Eeuw (Zutphen 2003), deel VII, 154.
} 
ical technology. The interest was representative of an accelerated development of the modern knowledge infrastructure at the end of the nineteenth century. The first Dutch engineering firm was that of J. van Hasselt and De Koning, founded in 1881. In 1890, the national government established three new agricultural experimental stations, followed in 1913 by a State Industrial Service for Small Businesses. Between 1900 and 1910 the number of private and industrial laboratories increased remarkably. ${ }^{21}$

With its new modern knowledge infrastructure, the Netherlands was able to adopt new key foreign technologies in order to develop them further in domestic settings: synthetic chemistry on the basis of sulphuric acid and sodium carbonate; communications technology including telegraphy, telephony and telecommunication; electrical technology with the incandescent lamp and the electrical motor; organic chemistry on the basis of coal and mineral oil and finally mechanical engineering with steam technology, the internal combustion engine and the automobile. ${ }^{22}$ In the course of the twentieth century, a number of these technologies would have a major impact on the issues of well-being and sustainability.

\subsection{The Monitor of 1910: Well-being and Sustainability from Three Perspectives}

How can we judge the endpoint of this period - around 1910 - in terms of wellbeing and sustainability? In this section we will shed light on this question from three perspectives. The perspective of 1850: to what extent was the societal agenda of the mid-nineteenth century realised? The perspective of 1910: which elements were praised by contemporary politicians and the public, what were the contemporary concerns and what was the agenda for the future? Finally, we look at the developments with present-day eyes. How do we judge the results of the period 1850-1910 by present-day norms? The monitor well-being 1910 provides a summary of the various perspectives (Table 11.1).

\footnotetext{
${ }^{21}$ J.J. Hutter, 'Nederlandse laboratoria 1860-1940, een kwantitatief overzicht', Tijdschrift voor de Geschiedenis der Geneeskunde, Natuurwetenschapen, Wiskunde en Techniek 9 (1986), nr.4, 153, graph 1.

${ }^{22}$ In the second half of the nineteenth century, scientific and technical developments in the Netherlands were mainly inspired by foreign examples. In some fields, however, the Netherlands played a leading role as in the field of dietetics with Gerrit Mulder (1802-1889) and in the application of 'proteins'. H.A.M. Snelders, De geschiedenis van de scheikunde in Nederland: Van alchemie tot chemie en chemische industrie rond 1900 (Delft 1993), deel 1, 93-102.
} 
Table 11.1 The monitor well-being of 1910 from the perspectives of 1850 and 1910 and the present-day perspective

\begin{tabular}{|c|c|c|c|c|c|c|}
\hline \multicolumn{3}{|c|}{ Dashboard well-being 'here and now' } & \multirow[b]{2}{*}{1910} & \multirow[b]{2}{*}{$\begin{array}{r}\text { Perspective } \\
1850\end{array}$} & \multirow[b]{2}{*}{$\begin{array}{r}\text { Perspective } \\
1910\end{array}$} & \multirow[b]{2}{*}{$\begin{array}{r}\text { Present } \\
\text { day } \\
\text { perspective }\end{array}$} \\
\hline Theme & Indicator & Unit & & & & \\
\hline Population & Number inhabitants & million & 5.9 & & & \\
\hline \multicolumn{7}{|c|}{ Material welfare and well-being } \\
\hline \multirow[t]{3}{*}{$\begin{array}{l}\text { Consumption, } \\
\text { income }\end{array}$} & $\begin{array}{l}\text { Consumptive } \\
\text { expenditures per } \\
\text { capita, constant } \\
\text { prices }\end{array}$ & $\begin{array}{l}\text { Index } \\
(1850=100)\end{array}$ & 200 & + & - & - \\
\hline & $\begin{array}{l}\text { Income inequality, } \\
\text { general }\end{array}$ & $\begin{array}{l}\text { Gini } \\
\text { coefficient } \\
0-1\end{array}$ & 0.47 & + & - & - \\
\hline & $\begin{array}{l}\text { Gender income } \\
\text { inequality }\end{array}$ & $\begin{array}{l}\text { \% difference } \\
\text { hourly wage } \\
\mathrm{M} / \mathrm{F}\end{array}$ & $?$ & + & - & - \\
\hline $\begin{array}{l}\text { Subjective } \\
\text { well-being }\end{array}$ & $\begin{array}{l}\text { Satisfaction with } \\
\text { life }\end{array}$ & Score $0-10$ & $?$ & $?$ & $?$ & $?$ \\
\hline \multicolumn{7}{|c|}{ Personal characteristics } \\
\hline Health & Life expectancy & year & 55 & + & - & - \\
\hline Nutrition & $\begin{array}{l}\text { Height (military } \\
\text { conscripts) }\end{array}$ & $\mathrm{cm}$ & 173 & + & - & - \\
\hline \multirow[t]{2}{*}{ Housing } & Housing quality & $\%$ slums & 60 & + & - & - \\
\hline & Public water supply & $\mathrm{m}^{3} /$ capita & 19 & + & - & - \\
\hline Physical safety & Victims of murder & $\begin{array}{l}\text { number per } \\
100.000 \\
\text { inhabitants. }\end{array}$ & 0.4 & + & + & + \\
\hline Labour & Unemployment & $\%$ workforce. & 3.3 & + & + & + \\
\hline Education & Level of education & years & 5.8 & + & 0 & - \\
\hline Free time & Free time & $\begin{array}{l}\text { hours per } \\
\text { week. }\end{array}$ & $?$ & + & - & - \\
\hline \multicolumn{7}{|c|}{ Natural environment } \\
\hline Biodiversity & MSA & $\begin{array}{l}\% \text { original } \\
\text { biodiversity }\end{array}$ & 54 & + & + & - \\
\hline \multirow[t]{2}{*}{ Air quality } & $\mathrm{SO}_{2}$ & $\mathrm{~kg} \mathrm{SO}_{2} /$ capita & 25 & + & + & + \\
\hline & $\begin{array}{l}\text { Greenhouse gas } \\
\text { emissions }\end{array}$ & $\begin{array}{l}\text { ton } \mathrm{CO}_{2} \\
\text { /capita }\end{array}$ & 3.8 & + & + & + \\
\hline Water quality & Public water supply & $\mathrm{m}^{3} /$ capita & 18.7 & + & - & - \\
\hline \multicolumn{7}{|c|}{ Institutional environment } \\
\hline Trust & Generalised trust & $\begin{array}{l}\text { \% population } \\
\text { with adequate } \\
\text { trust }\end{array}$ & ? & - & - & - \\
\hline $\begin{array}{l}\text { Political } \\
\text { institutions }\end{array}$ & Democracy & $\begin{array}{l}\text { Democracy- } \\
\text { index } 0-100\end{array}$ & 9.5 & - & - & - \\
\hline
\end{tabular}


Table 11.1 (continued)

\begin{tabular}{|c|c|c|c|c|c|c|}
\hline \multicolumn{3}{|c|}{ Dashboard well-being 'later' } & \multirow[b]{2}{*}{1910} & \multirow[b]{2}{*}{$\begin{array}{r}\text { Perspective } \\
1850\end{array}$} & \multirow[b]{2}{*}{$\begin{array}{r}\text { Perspective } \\
1910\end{array}$} & \multirow[b]{2}{*}{$\begin{array}{l}\text { Present day } \\
\text { perspective }\end{array}$} \\
\hline Theme & Indicator & Unit & & & & \\
\hline \multicolumn{7}{|l|}{ Natural Capital } \\
\hline Energy & $\begin{array}{l}\text { Energy } \\
\text { consumption }\end{array}$ & TJ /capita & 51 & + & + & 0 \\
\hline Non-fossil fuels & $\begin{array}{l}\text { Gross domestic } \\
\text { consumption }\end{array}$ & ton/capita & 3.8 & + & + & 0 \\
\hline Biodiversity & MSA & $\begin{array}{l}\text { \% original } \\
\text { biodiversity }\end{array}$ & 54 & + & + & - \\
\hline \multirow[t]{2}{*}{ Air quality } & $\mathrm{SO}_{2}$ emissions & $\mathrm{kg} \mathrm{SO}_{2} /$ capita & & + & + & + \\
\hline & $\begin{array}{l}\text { Greenhouse gas } \\
\text { emissions }\end{array}$ & ton $\mathrm{CO}_{2} /$ capita & 3.8 & + & + & + \\
\hline Water & $\begin{array}{l}\text { Public water } \\
\text { supply }\end{array}$ & $\mathrm{m}^{3} /$ capita & 19 & + & - & \\
\hline \multicolumn{7}{|l|}{$\begin{array}{l}\text { Economic } \\
\text { Capital: }\end{array}$} \\
\hline Physical capital & \begin{tabular}{|l|}
$\begin{array}{l}\text { Economic capital } \\
\text { stock/capita }\end{array}$ \\
\end{tabular} & \begin{tabular}{|l|} 
index \\
$(1850=100)$
\end{tabular} & 201 & + & + & + \\
\hline Financial capital & $\begin{array}{l}\text { Grossnational } \\
\text { debt }\end{array}$ & $\%$ gdp & 71 & + & + & - \\
\hline Knowledge & $\begin{array}{l}\text { Stock knowledge } \\
\text { capital }\end{array}$ & $\begin{array}{l}\text { Index } \\
(2010=100)\end{array}$ & $<0.5$ & + & 0 & - \\
\hline \multicolumn{7}{|l|}{$\begin{array}{l}\text { Human } \\
\text { Capital: }\end{array}$} \\
\hline Health & Life expectancy & years & 55 & + & - & - \\
\hline Labour & Unemployment & $\%$ workforce & 2.0 & + & + & + \\
\hline $\begin{array}{l}\text { Educational } \\
\text { level }\end{array}$ & Schooling & years & 5.8 & + & $\circ$ & - \\
\hline \multicolumn{7}{|l|}{\begin{tabular}{|l|} 
Social Capital: \\
\end{tabular}} \\
\hline Trust & Generalised trust & $\begin{array}{l}\% \text { population } \\
\text { with adequate } \\
\text { trust }\end{array}$ & $?$ & - & - & - \\
\hline $\begin{array}{l}\text { Political } \\
\text { institutions }\end{array}$ & Democracy & $\begin{array}{l}\text { democracy } \\
\text { index 0-100 }\end{array}$ & 9.5 & + & 0 & - \\
\hline
\end{tabular}

\begin{tabular}{|l|l|l|c|c|c|c|}
\hline Dashboard well-being 'elsewhere' & & & & \\
\hline Theme & Indicator & Unit & $\mathbf{1 9 1 0}$ & $\begin{array}{l}\text { Perspective } \\
\mathbf{1 8 5 0}\end{array}$ & $\begin{array}{l}\text { Perspective } \\
1910\end{array}$ & $\begin{array}{l}\text { Present day } \\
\text { perspective }\end{array}$ \\
\hline Welfare & & & & & & \\
\hline $\begin{array}{l}\text { Consumption, } \\
\text { income }\end{array}$ & Development aid & $\%$ GDP & - & + & 0 & - \\
\hline Natural capital & & & & & & \\
\hline Natural capital & $\begin{array}{l}\text { Import of raw } \\
\text { materials }\end{array}$ & ton/capita & 3.3 & + & + & - \\
\hline
\end{tabular}

(continued) 
Table 11.1 (continued)

Legend
\begin{tabular}{|c|l|}
\hline+ & Not problematic or not problematized \\
\hline- & Generally acknowledged as problematic \\
\hline O & Under discussion: different opinions about the scale and nature of the problems \\
\hline$?$ & Unknown \\
\hline
\end{tabular}

Note: The signs - and $\bigcirc$ in the column of 1910 are the then important problematic themes. The column for 1850 shows with + , which agenda items of 1850 were realized in 1910 or were not problematized in 1850 . The column of the contemporary perspective indicates with - which current themes would now be regarded as problematic. For the justification of the evaluation in the table, see the main text

\subsubsection{Perspective 1850: An Enticing Paradise}

What the monitor above all wants to express is the normative shift that occurred with respect to well-being and quality of life, in particular as regards poverty. From the perspective of 1850 - in terms of the political and societal agenda that then prevailed - the Netherlands had made great progress. The extent of extreme poverty had been radically reduced. Hunger had become a thing of the past. The Netherlander was healthier and lived longer. There was ample employment and the population was well-educated. Criminality was low. True, a large part of the population lived in slums and only a small part had access to clean drinking water, toilets and sewers. But public housing and public health were not issues of major concern to citizens in 1850 and were not on the political agenda. For the rest, the future of the Netherlands in 1910 looked quite auspicious through the eyes of 1850. Economic dynamics were such that the last remnants of extreme poverty would disappear. That alone was already a great accomplishment, but the expectations went further: the people would share in the increased level of well-being and would begin to enjoy a certain level of comfort and luxury.

In another respect too, considerable progress had been made according to the agenda of 1850. It is not to be found in the monitor because the issue of water management is not included. The rivers had for the most part been tamed thanks to normalisation and the digging of new river distributaries. Floods due to ice packs and ice jams had become pretty much a thing of the past.

In one respect the observer from 1850 would look with concern at the situation prevailing at the beginning of the twentieth century. It was the question whether democracy had developed positively with the considerable extension of suffrage. Increasing influence by all kinds of groups from among the people and the bourgeoisie had led to major tensions between rich and poor, between workers and capitalists, between Catholics and Protestants, and among religions, socialism and liberalism. 


\subsubsection{Perspective 1910: The New Agenda of the Turn of the Century}

The monitor (Table 11.1) further indicates the contents of the new agenda on wellbeing around 1910. The question of poverty had by no means been solved. Aside from the fact that a hundred thousand Netherlanders continued to live in extreme poverty, public health remained abysmal. Child mortality was high. Adults still succumbed in great numbers to tuberculosis, typhus and other epidemic diseases. The common people lived in miserable circumstances. Hygiene in and around the dwellings and hygienic facilities in general gave much cause for concern. The labour situation in factories was very worrisome. The Netherlands faced the major challenge of finding a solution for the social question. Popular welfare, public health, public housing and labour all demanded quantitative and qualitative improvements.

The solution of the social question also demanded structural social change. Two unsolved issues remained at the top of the political agenda, namely universal suffrage (and with it the participation of all layers and groups of the population, including women, in political life) and the subsidising of special (i.e. religiously informed) education (and with it influence on the education and forming of the next generations).

\subsubsection{Present-Day Perspective: Related and Deviant Values}

From a present-day perspective the beginning of the twentieth century was a turbulent period in which economic prosperity and a belief in progress were accompanied with uncertainties, struggle and tensions. The monitor well-being (Table 11.1) indicates that from a present-day perspective we would emphatically agree with the importance of the social question. The new values that were then emerging about the various aspects of quality of life, are now completely accepted. They provided the foundations of a normative and legal framework that would be elaborated by successive generations in the twentieth century. But there are also two striking departures from the then current agenda: the perspective on natural capital and on the colonies.

The dominant vision on natural capital at the time was strictly utilitarian. Nature was to be dominated and made to serve humans. Land had to be won at the expense of water, wastelands reclaimed and subsoil resources exploited. Hunting animals that were a nuisance to agriculture was necessary and had in fact been supported by a bounty system since 1851 . Neither civil society nor the political establishment breathed a word about the depletion of raw materials or about environmental damage due to the use of coal. Immediate neighbours could complain about the nuisance of smoke and soot on the basis of the Public Nuisance Act. But a discussion about the air as a collective good, the pollution of which threatened the quality of the environment, was still far in the future. We should of course realise that energy 
consumption at the time was considerably lower than at present and that levels of $\mathrm{SO}_{2}$ emissions were far below present-day norms.

Equally unproblematized, was the change in material flows. In the fossil-fuel supply chains, domestic turf was replaced by foreign coal, a situation that made the Netherlands vulnerable on the point of its energy supply. Circular flows in the food chains were increasingly replaced by linear material flows. At the start of the supply chains farmers used ever more artificial fertiliser and imported cattle fodder. There was no discussion about what to do with human and animal faeces at the end of the production and consumption chain, once they lost their function as manure. Faeces, particularly those emanating from cattle husbandry, would become a big problem in the twentieth century.

The situation was a bit different in regard to encroachments on and damage to nature. ${ }^{23}$ The urban bourgeoisie, with Amsterdam's elite in the vanguard, developed an increasing sensitivity to natural values. The confrontation with changes in the rapidly growing and industrialising cities will probably have played a role. The psychiatrist Frederik van Eeden, who with his colony Walden pursued a utopian society, repudiated cities '...that extend their filthy outskirts like diseased celltissues across the pure earth and that exhaust the life-force of humanity in a steady fire of luxury and sin...' ${ }^{24}$ Foreign examples will also have inspired the bourgeoisie, such as with the founding of the Animal Protection Society in 1861. Art also provided inspiration, particularly through the '1880s movement' (of poets, painters, and authors) that etherealised nature and the landscape. Eventually the nature-loving bourgeoisie itself experienced the landscape in the course of day-trips by train, bike or automobile. In 1899 they founded the Bird Protection Society, in 1901 the Netherlands Natural-Historical Society and in 1905 the Association for the Preservation of Natural Monuments. Nature conservation was far from a political issue on anything like the scale of the social question. Nonetheless the movement scored some success, for example with the Bird Law of 1912. This prohibited the capture of migratory birds for consumption. But utilitarian arguments still prevailed. That said, it was not about 'utility' for agriculture or economy, but about 'utility' for humans.

The second point on which today's normative framework deviates from the 1910 perspective is the issue of colonial policy. In the nineteenth century, the colonies were regarded as sources of profit. In particular, gains from the Dutch East Indies comprised a substantial part of the Dutch state budget in the 1850s and 1860s. Average profits from the Cultivation System in those years amounted to between

\footnotetext{
${ }^{23}$ For the following see: J.L. van Zanden and S.W. Verstegen, Groene geschiedenis van Nederland (Utrecht 1993), 179-187; H.J. van der Windt, En dan: wat is natuur nog in dit land? Natuur bescherming in Nederland 1880-1990 (Groningen 1995) and H. Rennes, 'Het Nederlandsche landschap in de twintigste eeuw', in: C. Boissevain, M. Bosboom and H. Rennes, Typisch Hollands! De verandering van het Nederlandse landschap en de collectie Knecht-Drenth, 1900-heden (Zutphen 2008), 59-65.

${ }^{24}$ Cited in: J. Bank and M. van Buuren, 'Utopisten en socialisten', in: 1900. Hoogtij van burgerlijke cultuur (Den Haag 2000), volume 3, 449.
} 
$45 \%$ and $50 \%$ of the tax income of the national government. ${ }^{25}$ Big projects like the construction of the railway network were financed with moneys from the colonies. On the other hand, there was the development in the colonies themselves of a monetary system, a land registry and infrastructures like the railways and irrigation systems. However these were intended primarily to help realise a financial surplus destined for the home country.

Dismantling of the Cultivation System took place in the second half of the 1860s. There had been repeated criticism of the Cultivation System from the left-liberal camp, but the chorus of criticism swelled on the publication of Multatuli's Max Havelaar in 1860. At the same time it became evident that private entrepreneurs had developed sufficient expertise and financial resources to assume the role of the Cultivation System. Over subsequent years private initiative turned out to perform better than the compulsory cultivation system. ${ }^{26}$

The liberalisation of the colonial economy had little effect on the standard of living of the farmers and coolies in the Dutch East Indies and on the widespread poverty, that considerably exceeded the extent of poverty in the Netherlands. ${ }^{27}$ What in the Netherlands began to be called the 'social question,' became 'ethical politics' in reference to poverty in the colonies. The concept was first introduced by the liberal politician Pieter van Brooshooft in 1901 and was promptly included in the queen's speech for that year. ${ }^{28}$ It referred to a 'debt of honour' that the Netherlands had to pay back or a 'moral calling' that the country had to fulfil. It was supposed to promote the independence of the Dutch East Indies. Initiatives were taken to promote public education, establish a public credit facility and to curb the privileges of native chiefs and rulers. Roads and irrigation works were further developed. The 'ethical politics' also served as legitimation for military expeditions to enforce changes. It did not, however, lead to the end of the colonial system.

From the perspective of 1910 the Netherlands faced a major challenge, namely the solution of the social question or in other words the improvement of quality of life in the broadest sense of the term. In addition, the tense political stalemates around education and suffrage demanded resolution. The struggle against the waters continued to be necessary, despite the fact that the threat of river floods seemed to have become a thing of the past.

From a present-day perspective we see two big issues looming in the background: the quality of natural capital (including the natural environment) and the colonial relationships.

\footnotetext{
${ }^{25}$ Van Zanden and van Riel, Nederland 1780-1914, tabel 5.1, 223. See especially the section 'Koloniale politiek en Batig Slot', 220-231.

${ }^{26}$ According to C. Fasseur, administrators in the Dutch East Indies had already started to reform the Cultivation System by the 1840s and 1850s. Van Zanden and van Riel, Nederland 1780-1914, 226.

${ }^{27}$ See for real wages in the Dutch East Indies in comparison with the Netherlands: table 4.6 Real wages of building labourers in selected countries, 1820s-2000s, in: J.L. van Zanden et al. (eds.), How was life? Global well-being since 1820 (OECD Publishing 2014), 81.

${ }^{28}$ E.B. Locher-Scholten, 'Brooshooft, Pieter (1845-1921)', in Biografisch Woordenboek van Nederland. URL:http://resources.huygens.knaw.nl/bwn1880-2000/lemmata/bwn1/brooshooft [12-11-2013]. Consulted December 2016.
} 
The biggest threat to well-being came from outside and was foreseen in the Netherlands by only a very few: the First World War. In many ways the war proved a turning point in Dutch history, not in the last place for the dance of well-being and sustainability.

\section{Literature}

Baggen, P. and E. Homburg (2003). 'Opkomst van een kennismaatschappij'. In J.W. Schot, H.W. Lintsen, A. Rip and A.A. Albert de la Bruhèze (Eds.), Techniek in Nederland in de twintigste eeuw - Deel VII. Zutphen: Walburg Pers.

Bank, J. and M. van Buuren (2000). 'Utopisten en socialisten'. In J. Bank and M. van Buuren (Eds.), 1900. Hoogtij van burgerlijke cultuur. Den Haag: SDU uitgevers.

Bouwens, B. and J. Dankers (2010). Tussen concurrentie en concentratie: Belangenorganisaties, kartels, fusies en overnames. Bedrifsleven in Nederland in de twintigste eeuw. Amsterdam: Boom.

Buiter, H. (2005). Riool, rails en asfalt: 80 jaar straatrumoer in vier Nederlandse steden (dissertation). Eindhoven: Technical University Eindhoven.

Davids, M., H.W. Lintsen, and A. van Rooij (2013). Innovatie en kennisinfrastructuur: Vele wegen naar vernieuwing. Vol. 5. Bedrijfsleven in Nederland in de Twintigste Eeuw. Amsterdam: Boom.

Hennes, R. (2008). 'Het Nederlandse landschap in de twintigste eeuw'. In C. Boissevain, M. Bosboom and H. Rennes (Eds.), Typisch Hollands! De verandering van het Nederlandse landschap en de collectie Knecht-Drenth, 1900-heden. Zutphen: Walburg Pers.

Houwaart, E. (1993). 'Medische statistiek'. In H.W. Lintsen et al. (Eds.) Geschiedenis van de techniek in Nederland: De wording van een moderne samenleving 1800-1890. Zutphen: Walburg.

Hutter, J. (1986). 'Nederlandse laboratoria, 1860-1940: Een kwantitatief overzicht'. Tijdschrift voor de Geschiedenis der Geneeskunde, Natuurwetenschappen, Wiskunde en Techniek, 9(54), $150-174$.

Leeuwen, M. (1998a). 'Armenzorg, 1800-1912: Van centrum naar periferie'. In J. van Gerwen and M. van Leeuwen (Eds.), Studies over zekerheidsarrangementen: Risico's, risicobestrijding en verzekeringen in Nederland vanaf de Middeleeuwen. Amsterdam: Nederlands Economisch Historisch Archief.

Leeuwen, M. (1998b). 'Armenzorg, 1912-1965: Erfenis van de Republiek'. In J. van Gerwen and M. van Leeuwen (Eds.), Studies over zekerheidsarrangementen: Risico's, risicobestrijding en verzekeringen in Nederland vanaf de Middeleeuwen. Amsterdam: Nederlands Economisch Historisch Archief.

Lintsen, H.W. (1980). Ingenieurs in Nederland in de negentiende eeuw: Een streven naar erkenning en macht. Den Haag: Nijhoff.

Lintsen, H.W. and J. Korsten (2007). De veerkracht van de Brabantse economie: De Kamers van Koophandel en de kracht van netwerken [1840-2015]. Hilversum: Verloren.

Nijhof, E. and A. van den Berg (2012). Het menselijk kapitaal: Sociaal ondernemersbeleid in Nederland. Amsterdam: Boom.

Rooy, P. de (2014). Ons stipje op de waereldkaart: De politieke cultuur van modern Nederland. Amsterdam: Wereldbibliotheek.

Schulte, J. (1959). 'De Kamer van Koophandel en fabrieken, 1842-1862'. In H. van den Eerenbeemt and H. Schurink (Eds.), De opkomst van Tilburg als industriestad: Anderhalve eeuw economische en sociale ontwikkeling. Vught: Stichting tot Bevordering van de Studie der Sociale en Economische Geschiedenis.

Snelders, H.A.M. (1993). De geschiedenis van de scheikunde in Nederland: Van alchemie tot chemie en chemische industrie rond 1900. Delft: Delft University Press. 
11 From Extreme Poverty to the Social Question. Well-being and Sustainability...

Velden, S. van der (2009). Stakingen in Nederland: Arbeidersstrijd, 1830-1995. Amsterdam: Amsterdam University Press.

Windt, H.J. van der (1995). En dan: wat is natuur nog in dit land? Natuurbescherming in Nederland 1880-1990. Groningen: Boom.

Woud, A. van der (2010). Koninkrijk vol sloppen. achterbuurten en vuil in de negentiende eeuw. Amsterdam: Bert Bakker.

Zanden, J.L. van and S.W. Verstegen (1993). Groene geschiedenis van Nederland. Houten: Het Spectrum.

Zanden, J.L. van and Riel, A. van (2000). Nederland 1780-1914: Staat, instituties en economische ontwikkeling. Amsterdam: Balans.

Zanden, J.L. van (2014). How was life? Global well-being since 1820. OECD.

Open Access This chapter is licensed under the terms of the Creative Commons Attribution 4.0 International License (http://creativecommons.org/licenses/by/4.0/), which permits use, sharing, adaptation, distribution and reproduction in any medium or format, as long as you give appropriate credit to the original author(s) and the source, provide a link to the Creative Commons license and indicate if changes were made.

The images or other third party material in this chapter are included in the chapter's Creative Commons license, unless indicated otherwise in a credit line to the material. If material is not included in the chapter's Creative Commons license and your intended use is not permitted by statutory regulation or exceeds the permitted use, you will need to obtain permission directly from the copyright holder. 